\title{
STUDI TINGKAT KEANDALAN SISTEM PROTEKSI KEBAKARAN PADA BANGUNAN APARTEMEN (Studi Kasus Apartemen Di Surabaya)
}

\author{
ADIWIDJAJA, Roy \\ Email: hobbiez_arch@yahoo.com
}

\begin{abstract}
ABSTRAK
Kondisi tingkat keandalan sistem proteksi kebaran adalah sistem yang dibangun melalui pengaturan kelengkapan tapak, sarana keselamatan, sistem proteksi pasif dan sistem proteksi aktif untuk evakuasi penghuni maupun petugas kebakaran dalam upaya penyelamatan pada bangunan apartemen. Digunakan AHP (Analitycal Hierarchy Process) dalam proses pembobotannya untuk mendapatkan Nilai Keandalan Sistem Keselamatan Bangunan. Studi untuk mendapatkan Nilai Keandalan Sistem Keselamatan Bangunan terhadap Kebakaran dan pada tahap pemanfaatan ini bangunan dan lingkungannya andal sesuai dengan fungsinya dan aman bagi manusia.
\end{abstract}

Kata kunci: Keandalan, sistem, kebakaran, bangunan, apartmen, lingkungan.

\begin{abstract}
The reliability condition of fire rescue system is a system built by setting the completeness of site, means of salvation, passive protection system and active protection system for occupants evacuation time and fire fighting in apartment. AHP (Analitycal Hierarchy Process) is used in the process to get the grade in reliability of a buildings security systems. The study is to obtain the value systems of fire and building safety certainty at this stage wheter the use of this building and its environment reliability in accordance with its function and is safe for humans.
\end{abstract}

Keywords: Reliability, system, fire, building, apartment, environment

\section{PENDAHULUAN}

Penduduk kota tumbuh dengan sangat cepat, hal ini menyebabkan kebutuhan akan rumah tinggal juga meningkat. Pembangunan perumahan meningkat menyebabkan ketersediaan lahan berkurang, hal ini menyebabkan harga tanah semakin mahal. Dibutuhkan solusi perumahan dengan nilai ekonomi lahan yang tinggi serta aman. Direncanakan suatu pembangunan hunian secara vertikal untuk memenuhi kebutuhan rumah yang efisien dalam penggunaan tanah, terjangkau, layak, sesuai peruntukan dan tata ruang.

Dalam perancangan bangunan bertingkat pertimbangan tidak semata-mata ditujukan mendapatkan biaya awal yang rendah, tetapi berorientasi pada berbagai kemungkinan yang akan terjadi pada saat bangunan tersebut difungsikan. "Dalam merancang bangunan bertingkat tinggi, di samping aspek arsitektural, seorang arsitek perlu mempertimbangkan berbagai aspek lainnya, seperti struktural, mekanikal, elektrikal dan biaya bangunan" (Juwana, 2005, p. 2). Bangunan merupakan suatu sistem yang terintegrasi terdiri dari rangkaian sub-sub sistem dimana salah satunya masalah penanggulangan kebakaran harus sudah terintegrasi dengan baik dalam bangunan mulai dari tahap perencanaan sampai dengan bangunan beroperasi.

Penelitian ini dilakukan untuk menilai keandalan sistem penyelamatan terhadap kebakaran pada bangunan apartemen di Surabaya. Apartemen memiliki karakteristik bangunan yang unik, berbeda dari segi kepemilikan awal dan pengguna. Apartemen dibangun dan direncanakan oleh pemilik bangunan awal yang pada akhirnya terjadi perubahan kepemilikan, digunakan dan dihuni oleh sekumpulan orang yang menempati bangunan tersebut. Sehingga segala resiko bangunan menjadi tanggung jawab pemilik satuan-satuan hunian secara bersama. Dari segi jumlah orang yang berada dalam bangunan memang sedikit sekali tetapi memiliki privasi dalam beraktivitas sehingga satu sama lain tidak saling mengetahui.

Acuan yang dipergunakan menjadi standar pengamatan dan pengkajian antara lain Peraturan Menteri Pekerjaan Umum no. 26/PRT/M/2008 tentang Persyaratan Teknik Sistem Proteksi Kebakaran pada Bangunan Gedung dan Lingkungan. 


\section{METODE PENELITIAN}

Observasi dengan melakukan pengamatan langsung di lokasi yang mencakup:

- Komponen kelengkapan tapak

- Komponen sarana penyelamatan

- Komponen sistem proteksi pasif

- Komponen sistem proteksi aktif yang berpengaruh terhadap sistem proteksi pasif.
Dalam pelaksanaan penelitian mengingat banyak keputusan yang bersifat kualitatif, dan dasar ukuran pencapaiannya adalah dengan menggunakan skala subyektif, maka untuk memperoleh keputusan yang obyektif digunakan metode Analitycal Hierarcy Process (AHP), seperti terlihat pada Gambar 1.

Dibantu dengan metode sistem penilaian pada Malcolm Baldrige Award yang disesuaikan dengan kriteria keandalan sistem keselamatan bangunan untuk membantu dalam usaha penilaian yang lebih obyektif.

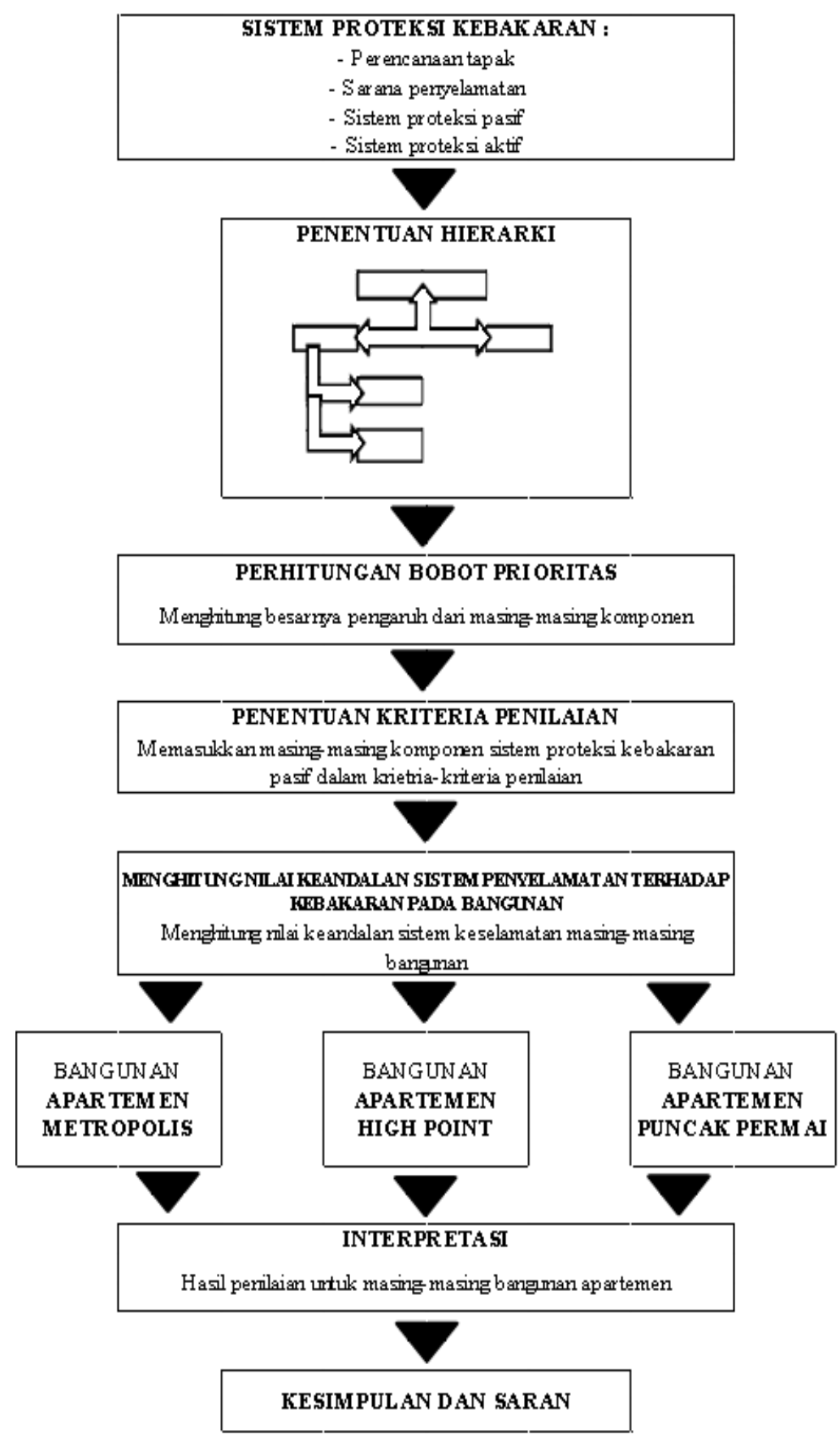

Gambar 1. Kerangka Berpikir 


\section{STUDI LITERATUR}

Acuan yang dipergunakan Peraturan Menteri Pekerjaan Umum no. 26/PRT/M/2008 tanggal 30 Desember 2008 tentang persyaratan Teknis Sistem Proteksi Kebakaran pada Bangunan Gedung dan Lingkungan, meliputi:

a. Sistem proteksi kebakaran pasif:

- Jalur akses masuk mobil pemadam kebakaran

- Lapis perkerasan, hidran halaman dan bukaan akses
- Akses petugas pemadam kebakaran di dalam bangunan

- Jarak antar bangunan

- Akses eksit, pintu dan tangga kebakaran dan eksit pelepasan

- Pencahayaan darurat

- Ketahanan struktur dan kompartemen.

b. Sistem proteksi kebakaran aktif yang mempengaruhi sitem proteksi kebakaran pasif:

- Sistem deteksi, penghisap asap dan springkler

- Pemadam api ringan dan hidran kebakaran Gedung.

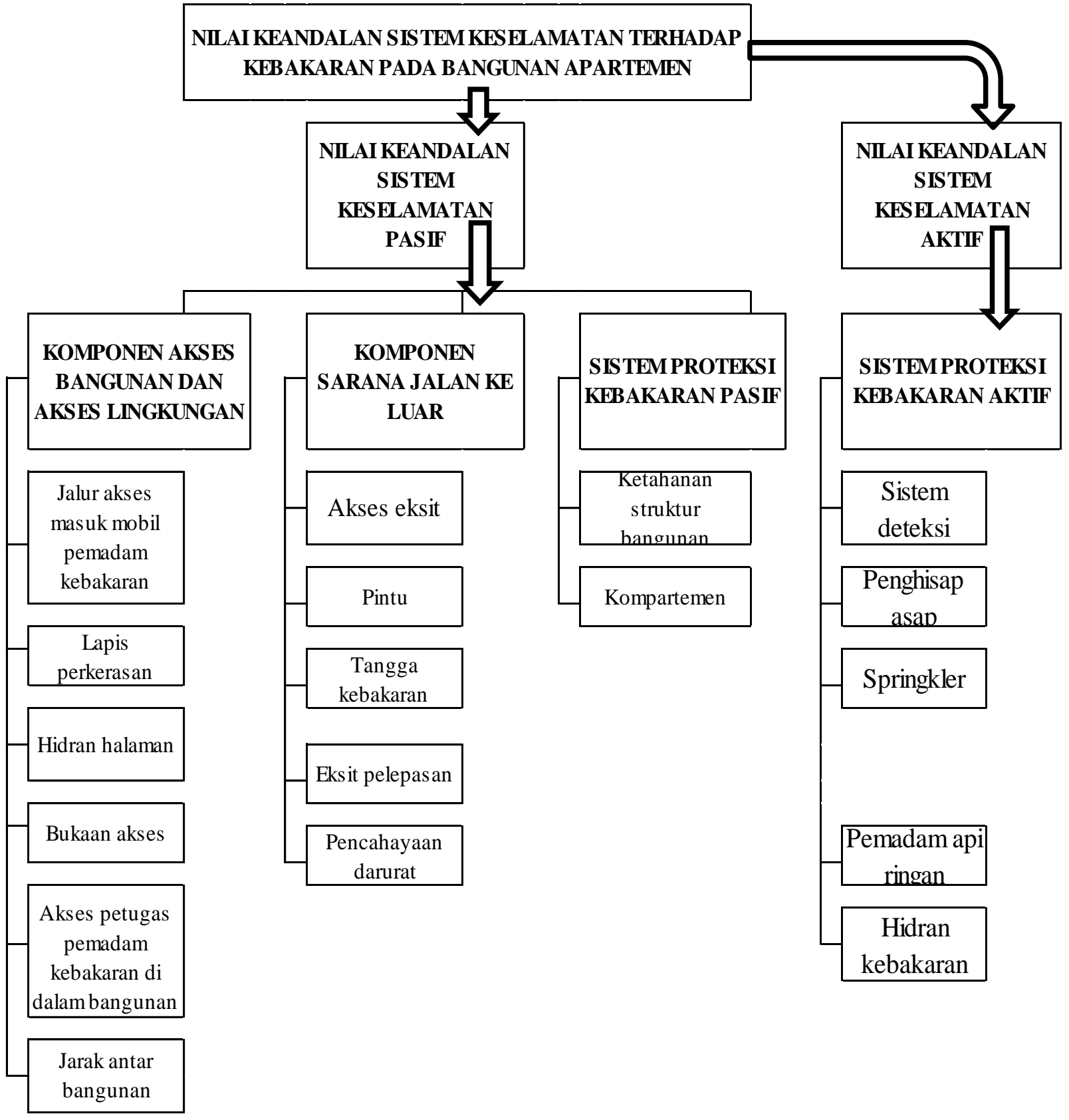

Gambar 2. Model Hierarki Lingkup Penelitan 


\section{PENELITIAN DAN PEMBAHASAN}

Pelaksanaan pengecekan keandalan bangunan terhadap bahaya kebakaran dilakukan dilapangan dengan observasi dan evaluasi berdasarkan acuan yang telah dibuat, mencakup:

- Komponen kelengkapan tapak

- Komponen sarana penyelamatan

- Komponen sistem proteksi pasif

- Komponen sistem proteksi aktif

Perhitungan bobot komponen sistem keselamatan bangunan dengan menggunakan metode AHP dan bantuan software Expert Choice terlihat hasilnya seperti Gambar 3.

Setiap komponen atau bagian dari bangunan harus dinilai keandalannya terhadap bahaya kebakaran. Nilai kondisi komponen sistem keselamatan pasif bangunan dibagi dalam lima tingkat yaitu:

- 4 komponen dan kelengkapan sesuai persyaratan

- 3 komponen sesuai persyaratan dan kelengkapan belum sesuai

- 2 komponen sesuai dengan persyaratan

- 1 komponennya belum sesuai dengan persyaratan minimal

- 0 tidak ada komponennya.

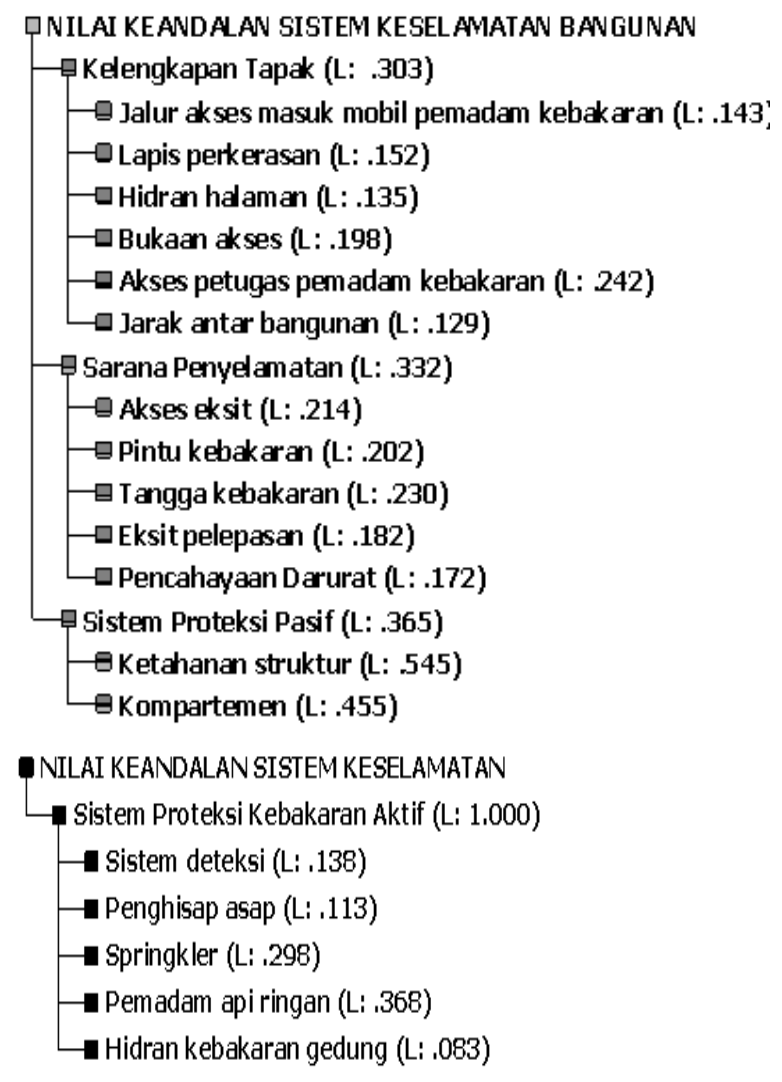

Gambar 3. Bobot Penilaian Komponen Sistem Keselamatan
Nilai kondisi komponen sistem keselamatan aktif bangunan dibagi dalam tiga tingkat yaitu:

- Baik (100) ... tersedia sesuai dengan persyaratan

- Cukup (80) ... tersedia tetapi tidak memenuhi kriteria

- Kurang (60) ... Tidak tersedia

Penelitian dilakukan pada bangunan:

- Apartemen Metropolis, Jl. Raya Tenggilis 127, Surabaya

- Apartemen High Point, Jl. Siwalankerto 161, Surabaya

- Apartemen Puncak Permai tower A, Jl. Raya Darmo Permai 3, Surabaya.

Nilai keandalan sistem keselamatan pasif (NKSKP):

- $0<$ NKSKP $<1$ : Tidak ada komponen sistem keselamatan bangunan.

- $1 \leq$ NKSKP < 2 : Terdapat komponen sistem keselamatan bangunan tetapi beberapa tidak memenuhi persyaratan

- $2 \leq$ NKSKP $<3$ : Terdapat komponen sistem keselamatan bangunan yang memenuhi persyaratan.

- $3 \leq$ NKSKP < 4 : Terdapat komponen sistem keselamatan bangunan yang memenuhi persyaratan tetapi dengan beberapa kelengkapan yang belum memenuhi persyaratan.

- NKSKP $=4$ : Komponen dan kelengkapan sistem keselamatan bangunan memenuhi persyaratan.

Untuk menjamin keselamatan bangunan secara keseluruhan, NKSKP nilainya harus 4 karena menyangkut keselamatan nyawa manusia. Nilai keandalan sistem keselamatan aktif (NKSKA):

$-60<$ NKSKA $<80$ : Terdapat beberapa sistem keselamatan bangunan yang tidak tersedia.

- $80<$ NKSKA < 100 : Terdapat sistem keselamatan bangunan tetapi beberapa tidak memenuhi persyaratan.

- NKSKA $=100 \quad$ : Semua sistem keselamatan bangunan dengan jumlah dan kelengkapannya memenuhi persyaratan.

Dari hasil pemeriksaan nilai keandalan sistem keselamatan bangunan yang telah dihitung maka dapat diketahui komponen keselamatan bangunan yang kurang memenuhi persyaratan dengan melihat pada catatan pada tabel penilaian untuk masingmasing bangunan. 
Tabel 1. Penilaian Keandalan Sistem Keselamatan Pasif

\begin{tabular}{|c|c|c|c|c|c|c|c|c|c|}
\hline \multirow{2}{*}{ Kriteria } & \multicolumn{3}{|c|}{ Metropolis } & \multicolumn{3}{|c|}{ High Point } & \multicolumn{3}{|c|}{ Puncak Permai (A) } \\
\hline & Nilai & Bobot & Jumlah & Nilai & Bobot & Jumlah & Nilai & Bobot & Jumlah \\
\hline Jalur akses masuk mobil pemadam kebakaran & 1 & 0.143 & 0.143 & 1 & 0.143 & 0.429 & 3 & 0.143 & 0.429 \\
\hline $\begin{array}{l}\text { Lapis perkerasan (dibuat dari lapiran yang dikerkuat } \\
\text { agar dapat menahan beban static mobil } \\
\text { pemadam kebakaran seberat } 44 \text { ton dengan } \\
\text { beban plat kaki jack) }\end{array}$ & 2 & 0.152 & 0.304 & 2 & 0.152 & 0.304 & 2 & 0.152 & 0.304 \\
\hline Hidran halaman & 1 & 0.152 & 0.135 & 1 & 0.135 & 0.135 & 4 & 0.135 & 0.54 \\
\hline $\begin{array}{l}\text { Bukaan akses (untuk petugas pemadam kebakaran } \\
\text { dibuat melalui dinding luar untuk operasi } \\
\text { pemadaman dan penyelamatan) }\end{array}$ & 2 & 0.198 & 0.396 & 2 & 0.198 & 0.396 & 2 & 0.198 & 0.396 \\
\hline $\begin{array}{l}\text { Akses petugas pemadam kebakaran di dalam } \\
\text { bangunan }\end{array}$ & 0 & 0.242 & 0 & 0 & 0.242 & 0 & 0 & 0.242 & 0 \\
\hline Jarak antar bangunan & 1 & 0.129 & 0.129 & 1 & 0.129 & 0.129 & 4 & 0.129 & 0.516 \\
\hline Nilai Komponen Kelengkapan Tapak & & & 1.107 & & & 1.393 & & & 2.185 \\
\hline $\begin{array}{l}\text { Akses Eksit (bagian dari sarana jalan keluar yang } \\
\text { menuju ke sebuah eksit) }\end{array}$ & 4 & 0.214 & 0.856 & 4 & 0.214 & 0.856 & 4 & 0.214 & 0.856 \\
\hline Pintu Kebakaran & 4 & 0.202 & 0.808 & 3 & 0.202 & 0.606 & 3 & 0.202 & 0.606 \\
\hline $\begin{array}{l}\text { Tangga Kebakaran (tangga yang direncanakan } \\
\text { khusus untuk penyelamaatan bila terjadi } \\
\text { kebakaran) }\end{array}$ & 3 & 0.230 & 0.69 & 1 & 0.230 & 0.23 & 3 & 0.230 & 0.69 \\
\hline $\begin{array}{l}\text { Eksit Pelepasan (bagian dari sarana jalan ke luar } \\
\text { antara batas ujung sebuah eksit dan sebuah jalan } \\
\text { umum) }\end{array}$ & 2 & 0.182 & 0.364 & 1 & 0.182 & 0.182 & 2 & 0.182 & 0.364 \\
\hline Pencahayaan Daarurat & 4 & 0.172 & 0.688 & 4 & 0.172 & 0.688 & 4 & 0.172 & 0.204 \\
\hline Nilai Komponen Sarana Penyelamatan & & & 3.406 & & & 2.562 & & & 3.204 \\
\hline Ketahanan Struktur & 4 & 0.545 & 2.18 & 4 & 0.545 & 2.18 & 4 & 0.545 & 2.18 \\
\hline Kompartemen & 4 & 0.455 & 1.82 & 1 & 0.455 & 0.635 & 4 & 0.455 & 1.82 \\
\hline Nilai Sistem Proteksi Kebakaran Pasif & & & 4 & & & 2.635 & & & 4 \\
\hline
\end{tabular}

Tabel 2. Penilaian Sistem Keandalan Keselamatan Aktif

\begin{tabular}{lccccccccc}
\hline \multirow{2}{*}{\multicolumn{1}{c}{ Kriteria }} & \multicolumn{3}{c}{ Metropolis } & \multicolumn{3}{c}{ High Point } & \multicolumn{3}{c}{ Puncak Permai (A) } \\
\cline { 2 - 10 } & Nilai & Bobot Jumlah & Nilai & Bobot Jumlah Nilai & Bobot Jumlah \\
\hline Sistem deteksi dan alarm kebakaran & 80 & 0.138 & 11.04 & 80 & 0.138 & 11.04 & 80 & 0.138 & 11.04 \\
Penghisap asap & 60 & 0.113 & 6.78 & 60 & 0.113 & 6.78 & 60 & 0.113 & 6.78 \\
Springkler & 80 & 0.298 & 23.84 & 80 & 0.298 & 23.84 & 80 & 0.298 & 23.84 \\
Alat pemadam api ringan & 80 & 0.368 & 29.44 & 60 & 0.368 & 22.08 & 60 & 0.368 & 22.08 \\
Hidran kebakaran gedung & 100 & 0.083 & 8.3 & 100 & 0.083 & 8.3 & 100 & 0.083 & 8.3 \\
\hline Nilai Sistem Proteksi Kebakaran Aktif & & & $\mathbf{7 9 . 4 0}$ & & & $\mathbf{7 2 . 0 4}$ & & $\mathbf{7 2 . 0 4}$ \\
\hline
\end{tabular}


Tabel 3. Nilai Keandalan Bangunan

Bangunan Apartemen Metropolis

\begin{tabular}{lccc}
\hline \multicolumn{1}{c}{ Kristeria } & Nilai & Bobot & Jumlah \\
\hline Penilaian Komponen Kelengkapan Tapak & 1.107 & 0.303 & 0.335421 \\
Penilaian Komponen Sarana Penyelamatan & 3.406 & 0.332 & 1.131 \\
Penilaian Sistem Proteksi Kebakaran pasif & 4 & 0.365 & 1.46 \\
\hline Nilai Keandalan Sistem Keselamatan Pasif terhadap Kebakaran & & & $\mathbf{2 . 9 2 6}$ \\
Nilai Keandalan Sistem Keselamatan Altif terhadap Kebakaran & & & $\mathbf{7 9 . 4 0}$
\end{tabular}

Bangunan Apartemen High Point

\begin{tabular}{llcc}
\hline \multicolumn{1}{c}{ Kristeria } & Nilai & Bobot & Jumlah \\
\hline Penilaian Komponen Kelengkapan Tapak & 1.393 & 0.303 & 0.422079 \\
Penilaian Komponen Sarana Penyelamatan & 2.562 & 0.332 & 0.851 \\
Penilaian Sistem Proteksi Kebakaran pasif & 2.635 & 0.365 & 0.961775 \\
\hline
\end{tabular}

Nilai Keandalan Sistem Keselamatan Pasif trhadap Kebakaran

2.234

Nilai Keandalan Sistem Keselamatan Aktif terhadap Kebakaran

72.04

\section{Bangunan Apartemen Puncak Permai}

\begin{tabular}{lccc}
\hline \multicolumn{1}{c}{ Kristeria } & Nilai & Bobot & Jumlah \\
\hline Penilaian Komponen Kelengkapan Tapak & 2.185 & 0.303 & 0.662055 \\
Penilaian Komponen Sarana Penyelamatan & 3.204 & 0.332 & 1.064 \\
Penilaian Sistem Proteksi Kebakaran paasif & 4 & 0.365 & 1.46 \\
\hline Nilai Keandalan Sistem Keselamatan paasif terhadap Kebakaran & & $\mathbf{3 . 1 8 6}$ \\
Nilai Keandalan Sistem Keselamatan Aktif terhadap kebakaran & & $\mathbf{7 2 . 0 4}$
\end{tabular}

\section{HASIL ANALISA}

- Dari hasil perhitungan nilai keandalan sistem keselamatan bangunan apartemen Metropolis adalah 2,926 $(79,40)$ artinya pada bangunan ini memiliki komponen sistem proteksi kebakaran pasif yang memenuhi persyaratan tapi kurang kelengkapan dan sistem proteksi kebakaran aktif kurang memadai.

- Dari hasil perhitungan nilai keandalan sistem keselamatan bangunan apartemen High Point adalah 2,234 $(72,04)$ artinya pada bangunan ini memiliki komponen sistem proteksi kebakaran pasif yang memenuhi persyaratan tetapi kurang kelengkapan dan sistem proteksi kebakaran pasif yang kurang memadai.

- Dari hasil perhitungan nilai keandalan sistem keselamatan bangunan apartemen Puncak Permai adalah 3,186 $(72,04)$ artinya pada bangunan ini memiliki komponen sistem proteksi kebakaran pasif yang memenuhi persyaratan tetapi kelengkapan kurang memenuhi persyaratan dan sistem proteksi kebakaran aktif yang kurang memadai.

\section{KESIMPULAN}

Dari hasil penelitian terlihat bahwa untuk masalah keselamatan bangunan terhadap bahaya kebakaran sangatlah kurang mendapat perhatian pada bangunan apartemen di Surabaya, masalah ini sebenarnya tidak boleh diabaikan dan harus tersedia dengan sempurna atau lengkap sesuai dengan yang dipersyaratkan karena kalau sampai terjadi kebakaran maka akan mengakibatkan kerugian harta benda dan yang terpenting keselamatan nyawa manusia.

Hal ini terjadi karena pembeli atau penghuni apartemen kurang mengerti/pemahaman tentang bahaya kebakaran sehingga hal ini dimanfaatkan oleh pengembang untuk mengurangi komponen sarana keselamatan di bangunan apartemen ini sehingga mampu menjual harga yang cukup terjangkau. Penghuni mungkin mengetahui beberapa komponen keselamatan bangunan tetapi tidak mengetahui secara rinci mengenai persyaratan yang dibutuhkan. Yang lebih bermasalah, pengembang biasanya mengetahui mengenai persyaratan ini baik melalui pihak perencana maupun bagian perijinan tetapi berusaha mengurangi atau meminimalkan komponen sistim proteksi untuk dapat menjual unit apartemen dengan harga murah.

\section{DAFTAR PUSTAKA}

Badan Standarisasi Nasional (2000) SNI 03-17352000: Tata cara Perencanaan Akses Bangunan dan Akses Lingkungan untuk Pencegahan Bahaya Kebakaran pada Bangunan Gedung.

Badan Standarisasi Nasional. (2000). SNI 03-17362000: Tata Cara Perencanaan Sistem Proteksi Pasif untuk Pencegahan Bahaya Kebakaran pada Bangunan Rumahdan Gedung. 
Badan Standarisasi Nasional. (2000). SNI 03-17462000: Tata Cara Perencanaan dan Pemasangan Sarana Jalan untuk Penyelamatan Terhadap Bahaya Kebakaran pada Bangunan Gedung.

Badan Standarisasi Nasional. (2000). SNI 01-75652002: Spesifikasi Bahan Bangunan untuk Pencegahan Bahaya Kebakaran pada Bangunan Rumah dan Gedung.

Departemen Pekerjaan Umum. (2008). Peraturan Menteri Pekerjaan Umum No.26/PRT/M2008, tentang: Persyaratan Teknis Sistem Proteksi Kebakaran pada Bangunan Gedung dan Lingkungan.
Juwana, J.S. (2005). Panduan Sistem Bangunan Tinggi. Erlangga, Jakarta

Saaty, T.L. (1993). Pengambilan Keputusan Bagi Para Pemimpin. Proses Hierarki Analitik untuk Pengambilan Keputusan dalam Situasi yang Kompleks. P.T.Pustaka Binaman Pressindo, Jakarta.

Tryon, George H. (1969). Fire Protection Handbook. National Fire Protection Association (NFPA). Massachussetts.

Undang-Undang Republik Indonesia No.28 Tahun 2002, Tentang: Bangunan Gedung. 